\title{
Influence of plug cell volume and substrate type on the development of cucumber seedlings for transplanting
}

\author{
Francis Kumi ${ }^{1}$, Faith Korkpoe ${ }^{1}$, and Gilbert Osei ${ }^{1}$ \\ ${ }^{1}$ Department of Agricultural Engineering, School of Agriculture, College of Agriculture and Natural \\ Sciences, University of Cape Coast, Ghana. \\ ${ }^{1}$ Correspondence: francis.kumi@ucc.edu.gh
}

\begin{abstract}
This study investigated the influence of plug cell volume (72 plug cell volume $(36 \mathrm{~mL})$ and 128 plug cell volume $(20$ $\mathrm{mL})$ ) and substrate type (peat and cocopeat) on the development of cucumber seedlings. The experiment was designed in a factorial arrangement in a completely randomized design with four replications. The following growth data were measured: seedling plant height, number of leaves, stem diameter as well as the shoot and root biomasses. The result showed significant differences among the treatments with respect to the seedling plant height, stem diameter, as well as the shoot and root biomasses. Overall, it was found that growing cucumber seedlings in 72 plug cell volume with cocopeat produces a better young plant for transplanting compared to using a 128 plug cell volume containing either cocopeat or peat.
\end{abstract}

Keywords: seedlings; peat; cocopeat; plug cell; substrate.

Citation: Francis Kumi, Faith Korkpoe, and Gilbert Osei. Influence of plug cell volume and substrate type on the development of cucumber seedlings for transplanting, 2019; 4(1): 50-62

Received: January 4, 2019

Accepted: July 5, 2019 


\subsection{Introduction}

Cucumber (Cucumis sativus) is the fourth most widely cultivated vegetable crop in the world after tomatoes, cabbage, and onions (Shetty and Wehner, 2002). China is the leading producer, contributing almost two-thirds of all world production (60\%) between 2000 and 2004 (Martinez et al, 2006). Turkey is the second highest producer with approximately 5\% of total cucumber production worldwide followed by Iran with an average production of 3.6\%, the U.S. $(2.7 \%)$ and Japan $(1.9 \%)$. It has been identified as one of the cultivated exotic vegetable crops that have gained popularity in Ghana with the potential of providing foreign exchange for the country (Sinnadurai, 1992; MOFA, 2002).

The optimum yield of cucumber on the field is dependent on a lot of factors including the conditions under which seedlings are raised (NeSmith and Duval, 1998). From the studies conducted by Ray and Sinclair, (1998), it was revealed that plug cells are required to hold the substrate and are key components for the growth and survival of seedlings. According to Al-Menaie et al., (2012), plug cell size has an effect on plant growth and it may affect root and shoot growth, biomass accumulation and partitioning, photosynthesis, leaf-chlorophyll content, plant water relations, nutrient uptake, respiration and flowering. According to Schrader (2000), smaller plug cells reduce production costs.

Additionally, the type of growth substrate used also influences the production of seedlings grown in plug cells. Hence, the use of suitable growing media or substrates is essential for production of quality horticultural crops. A good growing medium would provide sufficient anchorage to the plant, serves as reservoir for nutrients and water, allows oxygen diffusion to the roots and permits gaseous exchange between the roots and atmosphere outside the root substrate (Bhardwaj and Kendra, 2014). An ideal potting substrate should be free of weeds and diseases to facilitate handling and transportation (Landis et al., 2012). It should also be well drained and yet retain sufficient water to reduce the frequency of watering. Other parameters to consider include cost, availability, consistency between batches and the stability in the substrate overtime. Robbins and Michael (2009) noted that selection of the proper substrate components is critical to the successful production of plants.

Over the years, Ghana has been faced with low production of cucumber although the environmental conditions are favourable for large scale cucumber production. The low production of cucumber in Ghana could be attributed to several reasons including the fact that most farmers sow their seeds directly into the soil without properly nurturing the seedlings. Although it has been reported by Kumar and Raheman, (2010) that seedlings raised in plug cells with soilless media increases the proper development of the crop, this is largely not been practiced in the country. Also, the use of plug cells for raising has not been embraced by seedling producers in the country.

This study therefore aimed at investigating the influence of plug cell volume and substrate type on the development of cucumber seedlings prior to transplanting. Specifically, the influence of these factors on the cucumber seedling shoot and root growth was assessed. 


\subsection{MATERIALS AND METHODS}

\subsection{The study area}

The study was carried out at the A.G Carson's Technology Village of the School of Agriculture, University of Cape Coast, Ghana. The experimental area was located at the Engineering field which falls within the coastal savannah zone. The climatic condition of the area was described by Owusu-Sekyere et al (2010) to have of annual mean temperature and relative humidity of $28.2^{\circ} \mathrm{C}$ and $82.8 \%$ respectively.

\subsection{Plug trays and Substrates used in the experiment}

Two plug tray cells were used for this experiment. Each tray has a total area of $1352 \mathrm{~mm}^{2}$. The trays used include; 128 plug tray and 72 plug tray. The 128 plug tray has 128 individual cells from an area of $1352 \mathrm{~mm}^{2}$ whiles the 72 plug tray has 72 individual cells from an area of $1352 \mathrm{~mm}^{2}$. Figure 1 (a) and (b) show pictures of empty 128 and 72 cell trays. Comparing the two trays, the 128 plug tray has more cells making the volume of the individual cells smaller as compared to the 72 plug tray with fewer cells, i.e., the fewer the individual plug cells on a plug tray, the bigger the volume of the individual cells and vice versa. Each plug cell for 72 tray has a volume of $36 \mathrm{~mL}$ whiles, that of the 128 tray has a volume of $20 \mathrm{~mL}$ per cell. Therefore in this study individual plug cells in the 72 plug tray and 128 tray plug tray are referred to as 72 plug cell volume and 128 plug cell volume respectively.

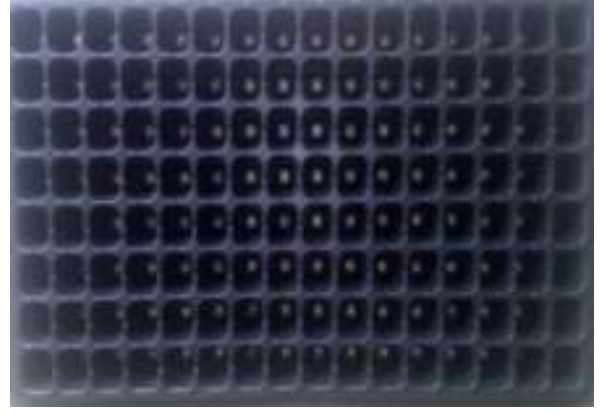

Figure 1: a. 128 plug tray.

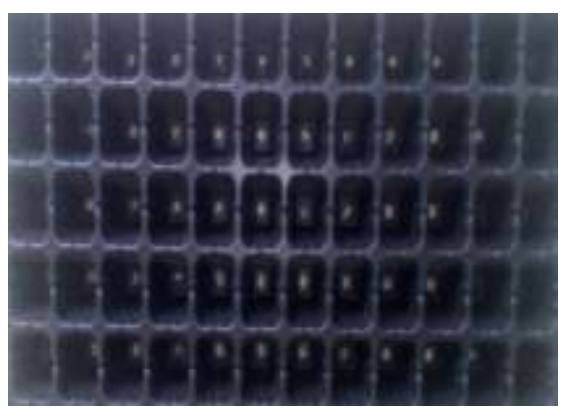

b. 72 plug tray.

The substrates used in the experiment were, peat and cocopeat. The peat substrate was purchased from Green Sun Garden Company Limited in Shanghai in the People's Republic of China. On the other hand, the cocopeat substrate was purchased from Green-Gro Company Limited Accra, Ghana. Table 1 shows the mean values of key chemical properties of the substrates used in the work.

Table 1: Chemical properties of the growing substrate

\begin{tabular}{llllll}
\hline Substrate & $\begin{array}{l}\mathrm{EC} \\
(\mathrm{mS} / \mathrm{cm})\end{array}$ & $\mathrm{pH}$ & $\begin{array}{l}\text { Nitrogen, } \\
\mathrm{N}(\%)\end{array}$ & $\begin{array}{l}\text { Phosphorus, } \\
\mathrm{P}(\mu \mathrm{g} / \mathrm{g})\end{array}$ & $\begin{array}{l}\text { Potassium, } \\
\mathrm{K}(\mathrm{cmol} / \mathrm{kg})\end{array}$ \\
\hline Peat & 0.152 & 5.76 & 0.11 & 26.40 & 1.42 \\
Cocopeat & 0.161 & 6.00 & 0.94 & 22.63 & 2.90 \\
\hline
\end{tabular}




\subsection{Experimental design}

The experimental design used in this study was a factorial arrangement in a Completely Randomized Design (CRD) with two factors (plug cell volume and substrate type). The treatments consisted of two levels of substrate fill and two levels of cell volume in a factorial combination to obtain 4 treatment combinations. The treatments imposed were peat and cocopeat based substrate fill and different plug cell volume of $36 \mathrm{~mL}$ (i.e 72 plug cell volume) and 20 $\mathrm{mL}$ (i.e 128 plug cell volume). There were four (4) replications.

\subsection{Sowing of seeds and seedling development}

Cucumber seeds (Kenzo variety) were sown on 29th March, 2017 at two seeds per cell in seedling containers/cells filled with substrates. The individual cells were placed on boxes with perforations. The boxes were placed under the rain shed. Labeling of the individual cells and replications was also carried out. After germination, thinning was done to reduce it to one seedling per cell as shown in Figure 2.

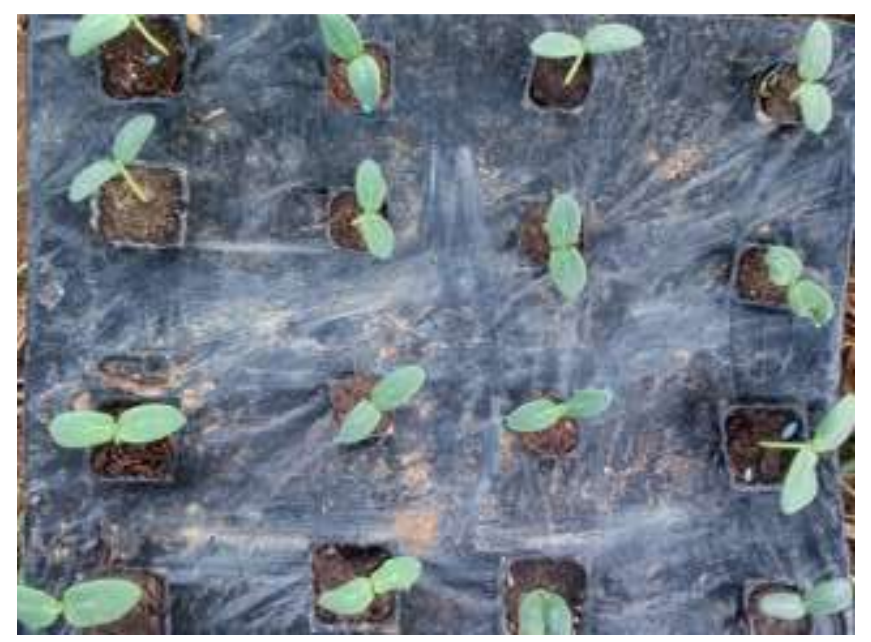

Figure 2: The seedlings growing after been sown in the plug cells

\subsection{Data collection}

Within five days, all the seeds had germinated and the number of leaves, plant height and shoot diameter were collected on weekly basis for three weeks on all seedlings.

\subsubsection{Seedling plant height}

The seedling plant heights were measured using a $30 \mathrm{~cm}$ rule from the base to the terminal leaf.

\subsubsection{Number of leaves}

The number of leaves was determined by manual counting. 


\subsubsection{Stem diameter}

This was determined using GuangLu electronic caliper and the values recorded in millimeters ( $\mathrm{mm})$.

\subsubsection{Shoot biomass}

On the $21^{\text {st }}$ day (three weeks), all plants were removed from their individual cells and washed. The shoots were separated from the roots through the use of a pair of scissors. The shoots were placed in a beaker and weighed using an electronic balance to obtain the fresh mass.

\subsubsection{Root biomass}

The roots detached from the shoots were placed in a beaker and weighed using an electronic to obtain the fresh mass.

\subsubsection{Root to shoot biomass ratio}

This was obtained by dividing the fresh biomass of the roots by the fresh biomass of the shoots.

\subsection{Statistical analyses}

The results of the study were subjected to two-way analysis of variance (ANOVA) using the general linear model in Minitab (version 17) software. ANOVA was conducted to predict the effect of the interaction of the experimental factors on stem diameter, plant height, number of leaves, shoot biomass, root biomass and root biomass: shoot biomass. Mean comparisons were done using the Tukey mean comparison test at a significance level of $5 \%$.

\subsection{RESULTS AND DISCUSSIONS}

\subsection{The effect of different plug cell volume and substrate type on seedling shoot growth (stem diameter, plant height and number of leaves).}

\subsubsection{Seedling plant height}

Figure 3 shows that both plug cell volume and substrate type have significant effects on seedling plant height $(\mathrm{p}<0.05)$. The 72 plug cell volume recorded the highest plant height compared to the 128 plug cell volume and this was evident in both peat and cocopeat growing substrates. This was similar to the findings of Bouzo and Favaro (2015) who stated that an increase in the container size results in plants of higher size. This is mostly due to the physical restriction of root by the use of containers with low volumes severely limit the plant growth after two weeks of sowing. Robbins and Pharr (1988) also reiterated that container size affect a number of physiological processes including nutrient efficiency and photosynthesis rates. Hence, a reduction in container cell volume limits resources such as nutrients, available growth medium and space for roots to spread and as such, root restriction will result in reduced plant growth. Generally, it was observed that cucumber transplants sown in cocopeat substrate were significantly higher than the plant height of cucumber seedlings raised in the peat substrate. The trend recorded in the seedling height could be attributed to the fact that cocopeat relatively has better chemical properties than peat as shown Table 1. A similar trend was observed in the 128 plug cell volume. It was also evident that plant height 
increases with the number of days in both the plug cell volume and the substrate type. The mean seedling heights in the 72 plug cell volume with cocopeat (abbreviated as 'coco' on all graphs) were $5.10 \mathrm{~cm}, 7.18 \mathrm{~cm}$, and $8.05 \mathrm{~cm}$ for day 7,14 , and 21 respectively whiles the mean heights revealed by the 72 plug cell volume with peat were $4.40 \mathrm{~cm}$, $6.85 \mathrm{~cm}$, and $7.48 \mathrm{~cm}$ for day 7,14, and 21 respectively. On the other hand, the height of seedlings in the 128 plug cell volume with cocopeat were $3.78 \mathrm{~cm}, 5.80 \mathrm{~cm}$, and $6.45 \mathrm{~cm}$ for day 7,14 , and 21 respectively whereas that in peat filled 128 plug cell volume were $3.35 \mathrm{~cm}, 5.00 \mathrm{~cm}$, and $5.80 \mathrm{~cm}$ for day 7,14 , and 21 respectively. The increase in seedling plant height through the growth period could be due to the fact that as the crop develops, the roots are able to pick up more water and nutrients whereas the leaves also undergo photosynthesis to produce photosynthate for plant growth.

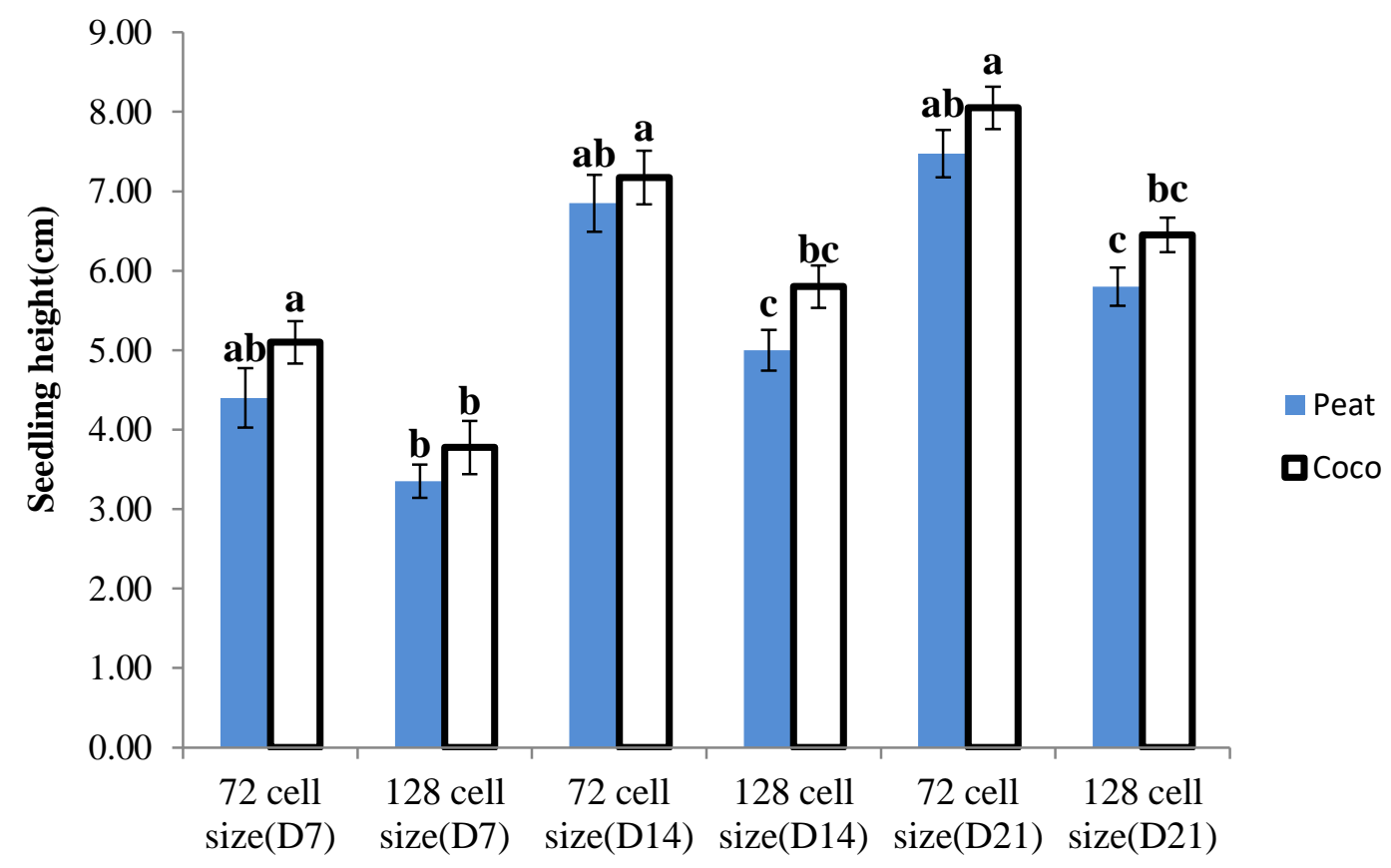

Plug cell volume (with substrate type) for days after sowing

Bars that do not share a letter are significantly different. D stands for days after sowing.

Figure 3: Effect of different plug cell volume and substrate type on seedling plant height.

\subsubsection{Number of Leaves}

The number of leaves was not significantly affected by the plug cell volume and substrate type and this is shown in figure 4 ( $\mathrm{p}>0.05)$. This implies that the plug cell volume and substrate type did not significantly affect the development of plant leaves for the first three weeks of planting. Similar findings was found by Oagile et al (2016). They stated that number of leaves showed a non-significant $(\mathrm{p}>0.05)$ difference in response to treatments in the first three weeks. They indicated that a reduction in container cell volume reduces the space for roots to spread which affect the uptake of available minerals from the growth medium and indirectly affecting other physiological processes such as photosynthesis and respiration. Though no significant differences were observed among the treatments, 
empirical observations showed that the number of leaves increased as plant age increased (from day 7 to 21) and this is displayed in figure 4. The increase in number of leaves as the plant ages is attributed to the ability of plant roots to absorb adequate nutrients and moisture and the ability of the leaves to receive sufficient sunlight to produce photosynthate to enhance their (i.e leaves) development

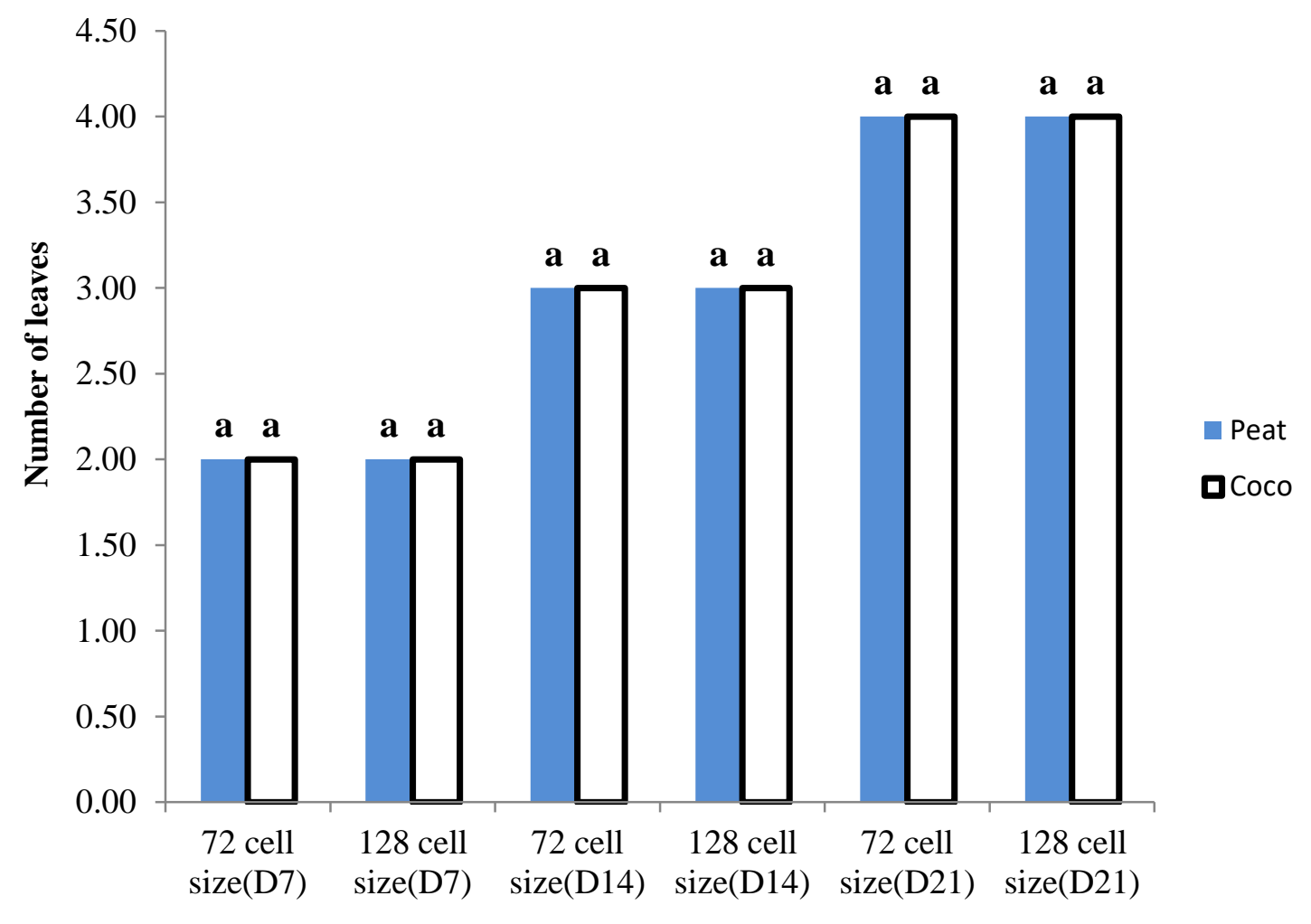

Plug cell volume (with substrate type) for days after sowing

Bars that do not share a letter are significantly different. D stands for days after sowing.

Figure 4: Effect of different plug cell volume on the number of leaves.

\subsubsection{Stem diameter}

From figure 5, the plug cell volume and substrate type had significant impact on stem diameter of cucumber seedlings. Further, the 72 plug cell volume recorded the highest stem diameter when compared with the stem diameter of transplants sown in the 128 plug cell size $(p<0.05)$. This could be as a result of the relatively adequate volume in the 72 plug cell volume in that, which allowed for more space for roots to expand and absorb nutrients and water from the substrates without much restriction. It was also observed that stem diameter increases with increasing plant age. This could be ascribed to the fact that as the cucumber seedling ages, its roots develop which enables it to pick up more moisture and nutrients. Comparison between the substrates in figure 5 showed significant difference at day 7 and 14 for transplants sown in substrates of 128 and 72 plug cell volumes respectively. The stem diameter of seedlings planted in the 128 plug cell volume with peat recorded the highest stem compared with 
seedlings raised in the 128 plug cell volume containing cocopeat. This could be as a result of high $\mathrm{N}$ immobilization by microorganisms and a high C:N ratio in cocopeat which has more than 50\% coir (Holman et al, 2002). From figure 5, it could be observed that the stem diameter of cucumber transplants sown in 72 plug cell volume with cocopeat showed the highest stem diameter compared to those in the 72 plug cell volume of peat. This can be attributed to the high chemical properties of the cocopeat substrate than the peat substrate.

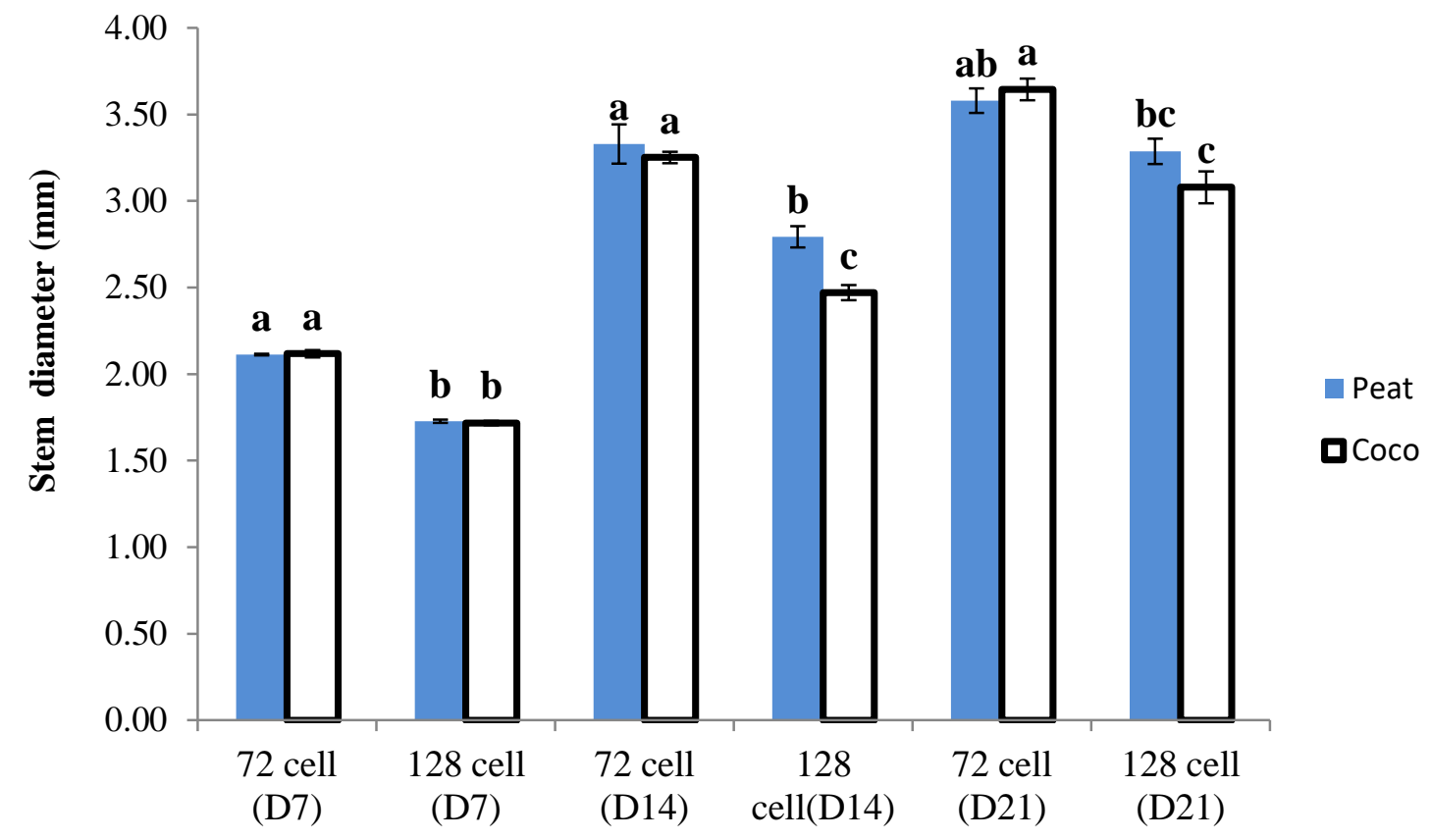

\section{Plug cell volume (with substrate type) for days after sowing}

Bars that do not share a letter are significantly different. D stands for days after sowing.

Figure 5: Effect of different plug cell volume and substrate type on stem diameter.

\subsection{The effect of plug cell volume and substrate fill on shoot and root biomass.}

\subsubsection{Shoot biomass}

Figure 6 shows that the experimental factors had significant impact on shoot biomass of cucumber seedlings $(\mathrm{p}<0.05)$. The 72 plug cell volume recorded the greatest shoot biomass as compared to the 128 plug cell volume and this was obvious in both cocopeat and peat growing substrates. This result is similar to the findings reported by Oagile et al., (2016) who stated that shoot weights is significantly $(\mathrm{p}<0.01)$ affected by varying container sizes with the highest results recorded for plants grown in larger plug cell volume.

According to NeSmith et al., (1992), reduced plant weights under root restricting conditions could possibly be due to a lower photosynthetic rate. From figure 6, it could be observed that the shoot biomass of cucumber seedlings raised in cocopeat substrate was significantly higher than the shoot biomass of seedlings in the peat substrate. The 
significant response observed in the shoot biomass could be attributed to the fact that cocopeat has better nutrient content (NPK) than peat. A similar development was observed in the 128 plug cell volume. The mean shoot biomass of cucumber seedlings in the 72 plug cell volume containing cocopeat was $1.05 \mathrm{~g}$ whereas the shoot biomass of seedlings in 72 plug cell volume with peat was $0.85 \mathrm{~g}$. The shoot biomass of cucumber seedlings grown in the 128 plug cell volume of cocopeat was $0.69 \mathrm{~g}$ whiles the shoot biomass of cucumber seedlings in the 128 plug cell size of peat was $0.60 \mathrm{~g}$.

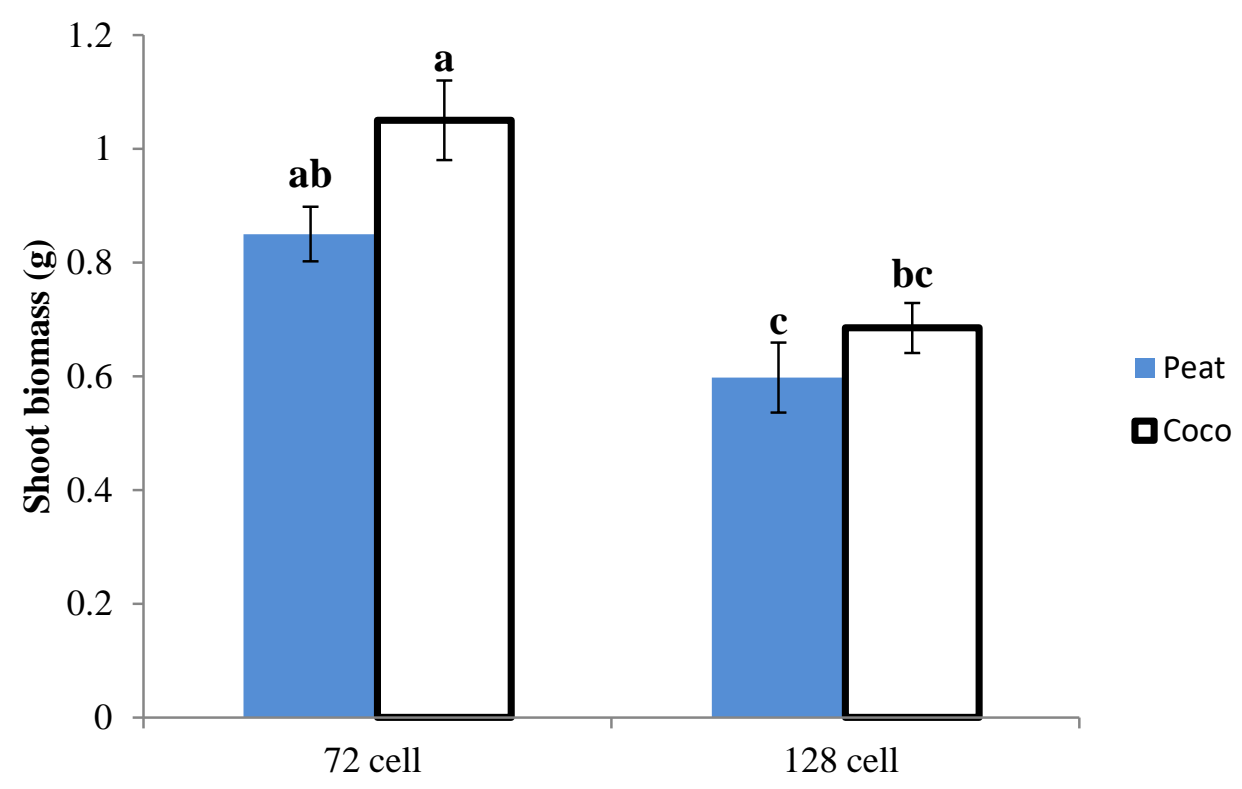

Plug cell volume (with substrate type)

Bars that do not share a letter are significantly different.

Figure 6: Effect of plug cell volume and substrate type on shoot biomass.

\subsubsection{Root biomass}

The root biomass of cucumber seedlings was significantly affected by the plug cell volume $(\mathrm{p}<0.05)$ but the substrate type did not show a significant effect on the shoot biomass $(\mathrm{p}>0.05)$. From figure 7 , the $72 \mathrm{plug}$ cell volume recorded the highest root biomass compared to the 128 plug cell size and this was evident in both peat and cocopeat growing media. The significant response revealed by the plug cell sizes could be attributed to the fact that the roots of the cucumber seedlings raised in the 72 plug cell volume had enough room to expand without being restricted by the cell size. This allowed the plant roots to absorb nutrients and water from the substrates to develop considerably. Optimal seedling root growth depends on favourable soil or media conditions including water, fertility, and the physical rooting environment (Leskovar et al., 1990).

From figure 7, it could be observed that although no significant differences existed between the root biomass of cucumber transplants raised in cocopeat substrate and that in the peat substrate $(\mathrm{p}>0.05)$, the latter produced a 
higher root biomass than the former. This could be attributed to the fact that, cocopeat, generally, has high $\mathrm{N}$ immobilization by microorganisms and a high C:N ratio in the coir (Holman, Bugbee, and Chard, 2002). A similar pattern was observed in the 128 plug cell volume for the two substrates. The mean root biomass of cucumber seedlings in the 72 plug cell volume of cocopeat was $0.56 \mathrm{~g}$ whereas the root biomass of peat raised cucumber seedlings in the 72 plug cell volume was $0.44 \mathrm{~g}$. The mean root biomass of cucumber plants grown in the 128 plug cell volume of cocopeat was $0.21 \mathrm{~g}$ whiles those in the 128 plug cell size of peat was $0.18 \mathrm{~g}$.

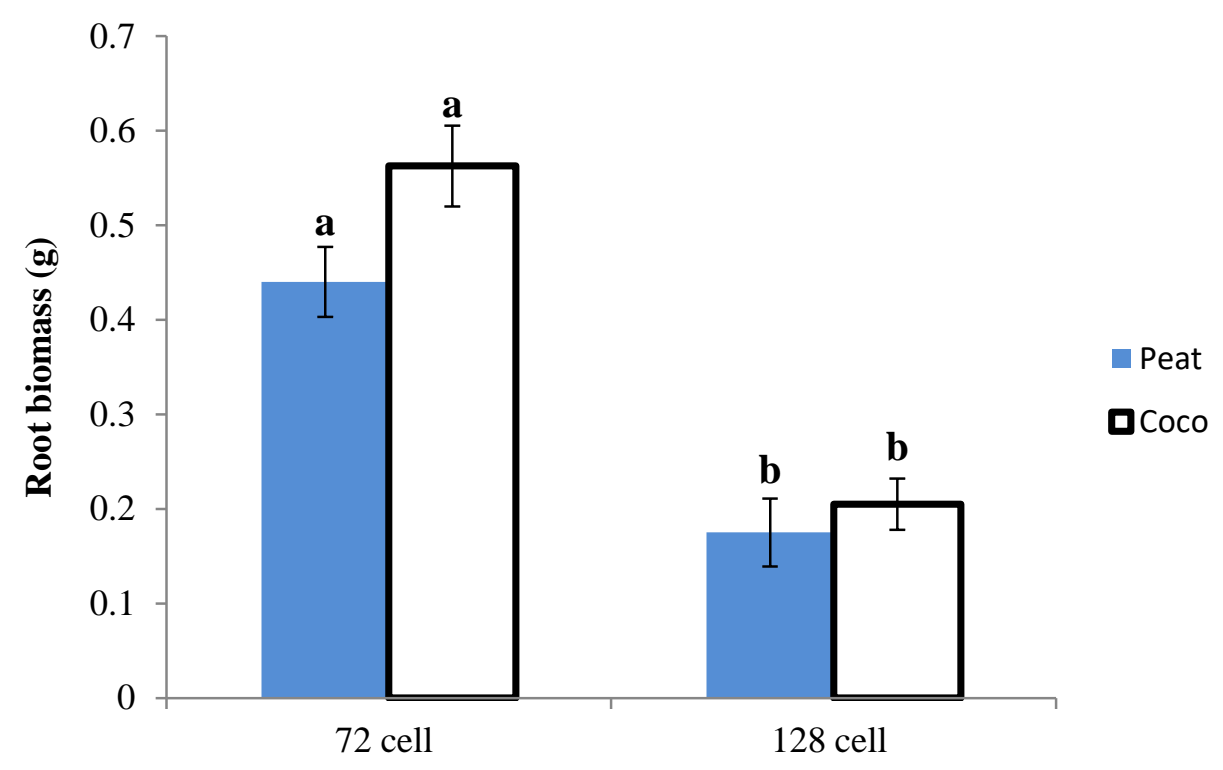

Plug cell volume (with substrate type)

Bars that do not share a letter are significantly different.

Figure 7: Effect of plug cell volume and substrate fill on root biomass.

\subsection{The optimal plug cell volume and substrate fill for producing quality cucumber seedlings.}

\subsubsection{Root biomass: Shoot biomass (RB:SB)}

Figure 8 shows the effect of plug cell volume and substrate type on the root biomass to shoot biomass (RB: SB) ratio of cucumber seedlings. It indicated a significant effect by the plug cell volume $(p<0.05)$ but the contrary for the substrate type in terms of the RB: SB. The 72 plug cell volume indicated the highest plant RB:SB as compared to the 128 plug cell volume and this was evident in both peat and cocopeat growing substrates. The significant differences revealed by the plug cell volume could be attributed to the fact that the roots of the cucumber seedlings raised in the 72 plug cell volume were not restricted by the cell size. This allowed the plant roots to absorb nutrients and water from the substrates to develop considerably. This could also be ascribed to varying container sizes and the consequences of the plant height, leaf number, and shoot growth. Seedlings with relatively large root systems generally suffer less post-transplant shock than plants with small root systems (Weston and Zandstra, 1986). From 
Figure 8 , it could be observed that no significant differences exist between the RB: SB of cucumber transplants raised in cocopeat substrate and that of the seedlings cultivated in the peat substrate $(\mathrm{p}<0.05)$. A similar development was observed in the 128 plug cell volume. The RB:SB of cucumber seedlings sown in the 72 plug cell volume of cocopeat was 0.53 whereas the RB:SB of peat raised cucumber seedlings in the 72 plug cell volume was 0.52 . The RB:SB of cucumber seedlings grown in the 128 plug cell volume of cocopeat was 0.30 whiles the RB:SB of cucumber seedlings shown by seedlings grown in the 128 plug cell volume with peat was 0.29 .

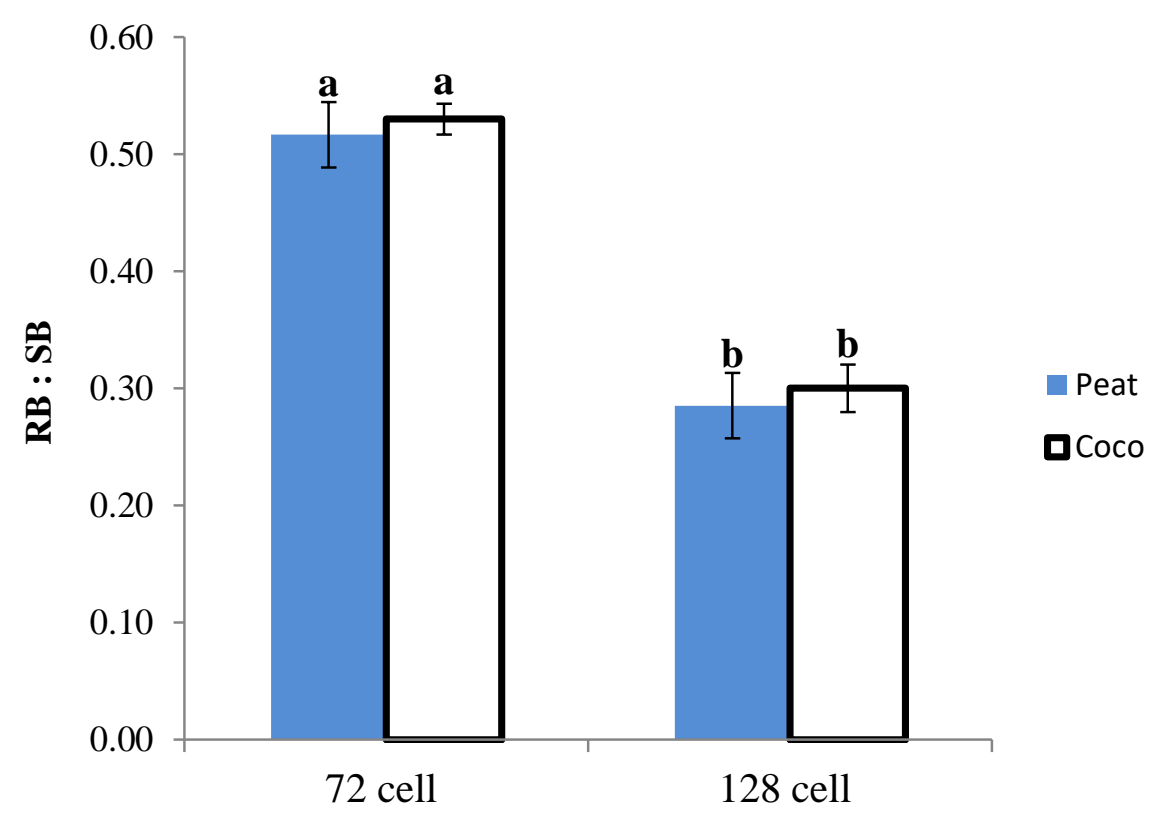

\section{Plug cell volume (with substrate type)}

Bars that do not share a letter are significantly different.

Figure 8: The effect of plug cell volume and substrate type on root biomass to shoot biomass ratio.

\subsection{Conclusion}

From the study, it was generally evident that the plug cell volume and substrate type had a significant effect on the shoots growth of the seedlings. The 72 plug cell volume containing cocopeat recorded the highest shoot growth compared to the 128 plug cell volume containing cocopeat. Also, the shoot and root biomass of seedlings raised in substrates of 72 plug cell volume were greater than the shoot and root biomass of the seedlings raised in substrates of 128 plug cell volume. Moreso, the root to shoot biomass ratio of seedlings raised in 72 plug cell volume with cocopeat was found to be higher than that of the seedlings raised in 72 plug cell volume with peat. This shows that for the development of high quality transplants, 72 plug cell volume containing cocopeat could be a better option to use. Hence, it could be concluded that, the 72 plug cell volume and cocopeat are good container and growth substrate, respectively, for the development of cucumber seedlings for transplanting. Future work could be done to 
determine the effects of different plug volume and substrate type on the survival of cucumber seedlings after transplanting unto the field.

\section{References}

1. Al-Menaie, H. S., Al-Ragam, O., Al-Dosery, N., Zalzaleh, M., Mathew, M. and Suresh, N. (2012). Effect of pot size on plant growth and multiplication of water lilies (Nymphaea spp), American-Eurasian Journal of Agriculture and Environmental Science. 12, 148-153.

2. Bhardwaj, R. L., and Kendra, K. V. (2014). Effect of growing media on seed germination and seedling growth of papaya cv. "Red lady ," 8(April), 178-184. https://doi.org/10.5897/AJPS11.265

3. Bouzo, C. A., and Favaro, J. C. (2015). Container size effect on the plant production and precocity in tomato (Solanumlycopersicum L.), Bulgarian Journal of Agricultural Science, 21(2), 325-332.

4. Holman, J., Bugbee, B., and Chard, J. (2002). A Comparison of Coconut Coir and Sphagnum Peat as Soil-less Media Components for Plant Growth, Hydroponics/Soilless Media. Paper 1.

http://digitalcommons.usu.edu/cpl_hydroponics/1

5. Jankauskienė, J., and Brazaityte, A. (2015). Effect of Different Growing Substrates on Physiological Processes, Productivity and Quality of Tomato in Soilless Culture. Soilless Culture - Use of Substrates for the Production of Quality Horticultural Crops

6. Kumar, G.V.P., and Raheman, H. (2010). Volume of vermicompost-based potting mix for vegetable transplants determined using Fuz:y biomass growth index. International Journal of Vegetable Science, 16:335-350.

7. Landis, T.D., Douglass F. J., Kim M.W., and Tara L., (2012). Tropical nursery manual : a guide to starting and operating a nursery for native and traditional plants. Agriculture handbook (United States. Department of Agriculture); 732, 100-119.

8. Leskovar, D.I., D.J. Cantliffe, and P.J. Stoffella. 1990. Root growth and rootshoot interaction in transplants and direct seeded pepper plants. J. Expt. Bot. 30:249354.

9. Liu, A. and Latimer, J. G. (1995). Root cell volume in the planter flat affects watermelon seedling development and fruit yield. Horticultural Science. 30, 242-246.

10. MOFA (2002). Ministry of Food and Agriculture Manual-Accra, 4: 54-56.

11. NeSmith, D. S., Bridges, D. C., and Barbour, J. C. (1992). Bell pepper responses to root restriction. Journal of Plant Nutrition. 15, 2763- 2776.

12. NeSmith, D. S., and Duval, J. R. (1998).The effect of container size. Horticultural Technology. 8, 495-498.

13. Oagile, O., Gabolemogwe, P., and Matsuane, C. (2016). Effect of container size on the growth and development of tomato seedlings, International Journal of Current Microbiology and Applied Sciences. 5(4), 890-896.

14. Owusu-Sekyere, J. D., Asante, P., and Osei-Bonsu, P., (2010). Water Requirement, Deficit Irrigation and Crop Coefficient of Hot Pepper (Capsicum frutescens) Using Irrigation Interval of Four (4) Days. ARPN Journal of Agricultural and Biological Science. 5(5), 72-78.

15. Ray, J. D. and Sinclair, T. R. (1998). The effect of pot size on growth and transpiration of maize and soybean during deficit stress. Journal of Experimental Botany. 49,1381-1386. 
16. Robbins, J.A and Michael, R.E (2009). Growing media for container production in greenhouse or nursery. Agriculture and Natural Resoruces. Available at http://www.uaex.edu. Accessed on 28 th March, 2017.

17. Robbins, N. S. and Pharr, D. M. (1988). Effect of restricted root growth on carbohydrate metabolism and whole plantgrowth of Cucumis sativus L. Plant Physiology. 87, 409-413.

18. Schrader, W. L. (2000). Using transplants in vegetable production. Publication 8013 by Division of Agriculture and Natural Resource, University of Californi $a$. http://anrcatalog.ucdavis.edu/pdf/8013 .pdf.Available online, retrieved 10- 10-2014.

19. Shetty, N and T.C. Wehner. (2002). Screening the Cucumber Germplasm Collection for Fruit Yield and Quality. Crop Science. 42:2174-2183.

20. Sinnadurai, S. (1992). Vegetable Cultivation. Asempa Publishers, Advent Press Accra. pp 3, 166-170.

21. Martinez, L, Thornsbury, S and Nagai, T (2006). Agricultural Economics Report (628)- National and International

22. Factors in Pickle Markets. Department of Agricultural Economics, Michigan States University. Available at https://core.ac.uk/download/pdf/6407521.pdf. Accessed on 4th May, 2017.

23. Weston, L.A. and Zandstra, B.H. (1986). Effect of root container size and location of production on growth and yield of tomato transplants. Journal of American Society of Horticultural Science. pp. 111, 498 - 501. 